\title{
37. MAGNETIC STRUCTURES OF SEAMOUNTS IN THE WESTERN PACIFIC OCEAN DEDUCED FROM LEG 144 DOWNHOLE MAGNETOMETER LOGS ${ }^{1}$
}

\author{
Hisao Ito $^{2}$ and Yoshifumi Nogi ${ }^{3}$
}

\begin{abstract}
Downhole magnetometer logs obtained during Ocean Drilling Program Leg 144 from Holes 873A (Wodejebato Guyot), 878A (MIT Guyot), and 879A (Takuyo-Daisan Guyot) in the western Pacific Ocean were used to constrain the nature and origin of the igneous sections of the seamounts. Magnetic boundaries, apparent inclination, polarity of magnetization (normal or reverse), and the hemispheric origin (Northern or Southern) was determined by inspecting the variations and the amplitudes of the horizontal and the vertical magnetic field.

Magnetization of the basalts between 175 and $200 \mathrm{mbsf}$ in Hole 873A (Wodejebato Guyot) was acquired during a reversed polarity chron in the Southern Hemisphere; the apparent inclination is about $21.6^{\circ}$. Magnetization below about 200 mbsf is most likely dominated by induced or viscous magnetization. The apparent inclination above $200 \mathrm{mbsf}$ is in good agreement with that derived from paleomagnetic studies of the core sample. Basalts from Hole 878A in MIT Guyot below 860 mbsf show that magnetization originated during a reversed polarity chron in the Southern Hemisphere. The apparent inclination below $860 \mathrm{mbsf}$ is $21.8^{\circ}$. Magnetization of basalts above $860 \mathrm{mbsf}$ possibly was acquired during a normal chron in the Southern Hemisphere. Magnetization of the basalts and volcaniclastic breccias in Hole 879A (Takuyo-Daisan Guyot) indicate an origin in the Southern Hemisphere during a normal polarity chron. The apparent inclination $\left(-20.6^{\circ}\right)$ is almost the same as that of the core-sample measurements.

Many magnetic boundaries were obtained from the logs of Holes 873A (Wodejebato Guyot) and 878A (MIT Guyot). These boundaries were not caused by changes in magnetic polarity but by intensity variations within the same polarity.

In this study, we suggest that induced magnetization in the upper basalt section is not significant in Wodejebato (Site 873), MIT (Site 878), and Takuyo-Daisan (Site 879) guyots.
\end{abstract}

\section{INTRODUCTION}

If one is to understand the origin of seamounts and absolute plate motion, one must know the magnetic properties of seamounts. In spite of numerous studies on magnetization of seamounts from magnetic anomalies (e.g., Sager and Pringle, 1988; Sager et al., 1993), the magnetic structure of seamounts is still unclear. Previous paleomagnetic studies on dredged and drilled samples from seamounts and islands show that the magnetic properties of seamount rocks are highly variable (Furuta et al., 1980; Kono, 1980; Gee et al., 1988, 1989). Gee et al. (1989) suggest that induced magnetization significantly contributes to seamount magnetization. Sager and Han (1993) found a low Koenigsberger ratio (Q ratio; i.e., the ratio of remanent magnetization to induced magnetization) in the southern Shatsky Rise. On the other hand, Sager and Pringle (1988) suggest that the magnitude of seamount magnetization derived from the seamount magnetic anomaly is almost the same as that obtained from dredged samples and that the induced magnetization of seamounts is negligible. Pillow basalts dredged from seamounts show high $\mathrm{Q}$ ratios (Furuta et al., 1980; Gee et al., 1988).

Downhole measurements of the magnetic field in boreholes are a useful counterpart to paleomagnetic studies if one is to obtain an insight into the nature of the magnetic structure of the oceanic crust and seamounts and of magnetic polarity stratigraphy.

Because core samples may acquire a secondary magnetization effect during the drilling process (Kikawa and Pariso, 1991; Nogi et al., in press a), the measured natural remanent magnetization (NRM) for recovered core samples may not accurately represent the in situ magnetization (Pariso and Johnson, 1993). Downhole logging can

${ }^{1}$ Haggerty, J.A., Premoli Silva, I., Rack, F., and McNutt, M.K. (Eds.), 1995. Proc. $O D P_{2}$ Sci. Results, 144: College Station, TX (Ocean Drilling Program).

${ }_{3}$ Geological Survey of Japan, Tsukuba, Ibaraki 305, Japan.

${ }^{3}$ Meteorological Research Institute, Tsukuba, Ibaraki 305, Japan. (Present address: National Institute of Polar Research, 1-9-10 Kaga, Itabashi, Tokyo 173, Japan.) collect a continuous record of downhole magnetic field, which can be related to the magnetization of the surrounding material in order to accommodate poor recovery of paleomagnetic samples from the holes and to give independent information on the magnetization. Therefore, it is necessary to combine the results from the core-sample measurements and downhole logging to understand the magnetic structure and paleomagnetic stratigraphy fully.

Many attempts have been made to develop a three-component downhole magnetometer and methods to analyze the three-component data (Bosum and Scott, 1988; Gallet and Courtillot, 1989; Kinoshita et al., 1989; Bosum and Kopietz, 1990; Hamano and Kinoshita, 1990; Pariso and Johnson, 1993; Nogi et al., in press b and c; Ito et al., this volume). It has been demonstrated that three-component downhole magnetometer logging results can reveal the magnetic structure of the oceanic crust and the origin of the magnetic anomaly lineations (Kinoshita et al., 1989; Hamano and Kinoshita, 1990; Pariso and Johnson, 1993; Ito et al., this volume), the magnetic structure of seamounts (Nogi et al., in press b), and the magnetization of sediments (Nogi et al., in press c).

Three-component downhole magnetometer logs were conducted for the first time in the holes of seamounts during Ocean Drilling Program (ODP) Leg 143 at Sites 865 and 866 (Nogi et al., in press b), which penetrated the upper igneous sections of the seamounts. Nogi et al. (in press b) suggest significant contribution of induced magnetization to seamount magnetization from the comparison of the threecomponent downhole data with paleomagnetic results for discrete core samples.

ODPLeg 144 drilled five guyots in the northwestern Pacific Ocean, and downhole measurements in the basement section were taken in Holes 873A (Wodejebato Guyot), 878A (MTT Guyot), and 879A (Takuyo-Daisan Guyot). Because the Japanese three-component downhole magnetometer that was used during Leg 143 (Nogi et al., in press $\mathrm{a}$ and $\mathrm{b}$ ) encountered serious trouble during the operation at Hole $873 \mathrm{~A}$, we present the results of an analysis of the data obtained with the Schlumberger general purpose inclinometer tool (GPIT), which was attached to the Formation MicroScanner (FMS). 


\section{DATA}

\section{Schlumberger GPIT}

A three-axis fluxgate magnetometer (GPIT) is routinely attached to the Schlumberger FMS tool to determine the horizontal tool orientation of the FMS tool relative to magnetic north. Because the resolution of the GPIT is at most $50 \mathrm{nT}$ (A. Dumont, pers. comm., 1992), it is almost impossible to analyze the data obtained with the GPIT in the weakly magnetized carbonate section. Therefore, we will concentrate on an analysis of the basalt section, which has a strong magnetization.

The GPIT has another problem inhibiting detailed magnetic analysis. Nogi et al. (in press b) found differences in the magnetic field between GPIT and the Japanese three-component downhole magnetometer by comparing both data obtained in the same well during Leg 143.

Measurements within the upper carbonate platform series in Hole 878A (Shipboard Scientific Party, 1993, fig. 45) show unknown drifts in both the vertical and horizontal components. The amount of these drifts is much larger than the magnetic anomaly that is expected in limestone. In addition, the horizontal component has several spikes in intensity. According to modeling of the borehole magnetometer response (e.g., Pozzi et al., 1988; Gallet and Courtillot, 1989), the magnetic intensities of the carbonate and sediments are too weak to cause magnetic anomalies of this magnitude. However, Nogi et al. (in press c) concluded that FMS/GPIT data can be used to estimate gross magnetic features with wavelengths larger than $10 \mathrm{~m}$.

At Wodejebato Guyot, Hole 873A was logged from the volcanic edifice through the carbonate platform succession with two passes of the geophysical string, two passes of the FMS/GPIT string, and one pass of the geochemical tool string (Shipboard Scientific Party, 1993). Two intervals of Hole 878A (MIT Guyot) were measured with the FMS/GPIT tool. The first set of measurements (two passes) was made within the lower igneous complex from 806.7 to 885 mbsf, corresponding to Cores 144-878A-87R through -94R. The second set of FMS/GPIT logs was through the carbonate platform succession (two passes) from 10 to $735 \mathrm{mbsf}$. The complete carbonate platform and igneous complex in Hole 879A at the southern rim of TakuyoDaisan Guyot were logged once with the geophysical string and twice with the FMS/GPIT tool string. Logging measurements were obtained from approximately $210 \mathrm{mbsf}$, corresponding to the upper part of Core 144-879A-23R, or about $17 \mathrm{~m}$ above the base of the hole, to the base of the drill pipe at $40.5 \mathrm{mbsf}$, corresponding to the lower part of Core 144-879A-5R.

\section{DATA PROCESSING}

\section{Magnetic Boundaries}

Magnetic boundaries between sections that have different hemispheres of origin and polarity are determined by the signs of the variations of the horizontal and vertical magnetic fields in the hole with respect to the present magnetic field and the peaks of the spatial differential of the downhole magnetic field (ISDDM), defined as follows (Nogi et al., 1993b; Ito et al., this volume):

$$
\left|\frac{d F}{d z}\right|=\sqrt{\left(\frac{d F_{H}}{d z}\right)^{2}+\left(\frac{d F_{Z}}{d z}\right)^{2}}=I S D D M
$$

where $F_{H}$ and $F_{Z}$ are horizontal and vertical magnetic fields derived from the surrounding magnetized material, and $z$ is depth (downward direction is taken as positive). Nogi et al. (in press b) showed that the ISDDM peaks coincide with the magnetic boundaries if enough distance is present between the magnetic boundaries.

Simple model calculation (Hamano and Kinoshita, 1990) shows that magnetic field variations at the magnetic boundaries differ for the possible four magnetization configurations: normal to reverse transition in the Northern Hemisphere, reverse to normal transition in the
Northern Hemisphere, normal to reverse transition in the Southern Hemisphere, and reverse to normal transition in the Northern Hemisphere. We define the sign of the horizontal field, the sign of the vertical field, and the sign of the vertical/horizontal components as $s\left(F_{H}\right), s\left(F_{Z}\right)$, and $s\left(d F_{Z} / d F_{H}\right)$, respectively. Table 1 shows the possible four magnetization configurations. For example, in the case of a normal to reverse transition in the Northern Hemisphere, the horizontal component increases $\left(s\left(F_{H}\right)\right.$ is positive) and the vertical component decreases $\left(s\left(F_{Z}\right)\right.$ is negative). Table 1 also shows that $s\left(d F_{Z} / d F_{H}\right)$ is always negative (variations in horizontal and vertical components are opposite to each other if the magnetization originated in the Northern Hemisphere, and that $F_{2} / F_{H}$ is always positive if the magnetization originated in the Southern Hemisphere. Thus, we can determine uniquely the polarity (normal or reverse) and hemisphere of origin (north or south) of magnetization by inspecting $s\left(F_{H}\right), s\left(F_{Z}\right)$, and $s\left(d F_{Z} d d F_{H}\right)$ (Nogi et al., in press b; Ito et al., this volume).

Because unknown drift was observed in the magnetic field by GPIT, we estimated the limit of uncertainty using magnetic variation in the carbonate section. The sign of the horizontal and vertical component of the magnetic field was defined using values above and below these uncertainty limits. Magnetic field variations within these uncertainty limits are not used for the present analysis. Smoothed spatial differential values of horizontal and vertical magnetic field according to Savitzky and Golay (1964) are used to calculate ISDDM and the apparent inclination in order to estimate their average features. Nine-point smoothing is made. This smoothing interval corresponds to $1.35 \mathrm{~m}$. The threshold level of ISDDM is taken as 2000 $\mathrm{nT} / \mathrm{m}$. Magnetic units are determined by inspecting the signs and variations of horizontal and vertical components.

\section{Apparent Inclination}

Apparent inclination $(I)$ also is obtained using the ratio of the vertical to the horizontal component of the magnetic field (Nogi et al., in press b):

$$
I=\tan ^{-1}\left(-\frac{F_{Z}}{2 F_{H}}\right)
$$

Apparent inclination was determined within the igneous rock section in each hole. Because the range between the estimated horizontal and vertical components of the present magnetic field is uncertain because of unknown drifts, we used a spatial differential of the vertical and horizontal components of magnetic variation $\left(s\left(F_{Z}\right)\right.$ and $d F_{H} / d z$, respectively). Apparent inclination was calculated by correlating the spatial differential of the magnetic field of vertical and horizontal components in each hole.

This provides us with new information from the downhole threecomponent magnetometer data because the ambiguity, combined with the lack of horizontal orientation of the core samples, means it is impossible to distinguish, for example, between normally magnetized basalts formed in the Northern Hemisphere and reversely magnetized basalts formed in the Southern Hemisphere simply with the remanent inclination of the basalt samples.

\section{RESULTS}

\section{Hole 873A (Wodejebato Guyot)}

There are two magnetic units in Hole 873A (Fig. 1). At the upper boundary of Magnetic Unit 1 (175 mbsf), there is a gradual decrease in both the vertical and horizontal components of the downhole magnetic field at about 175 mbsf, coinciding with the reddish brown clay/weathered basalt boundary at $174 \mathrm{mbsf}$ (Fig. 1). At the lower boundary (202 mbsf), corresponding to a weathered basalt/volcaniclastic breccia lithologic boundary at $200 \mathrm{mbsf}$, both the horizontal and vertical components increase. 


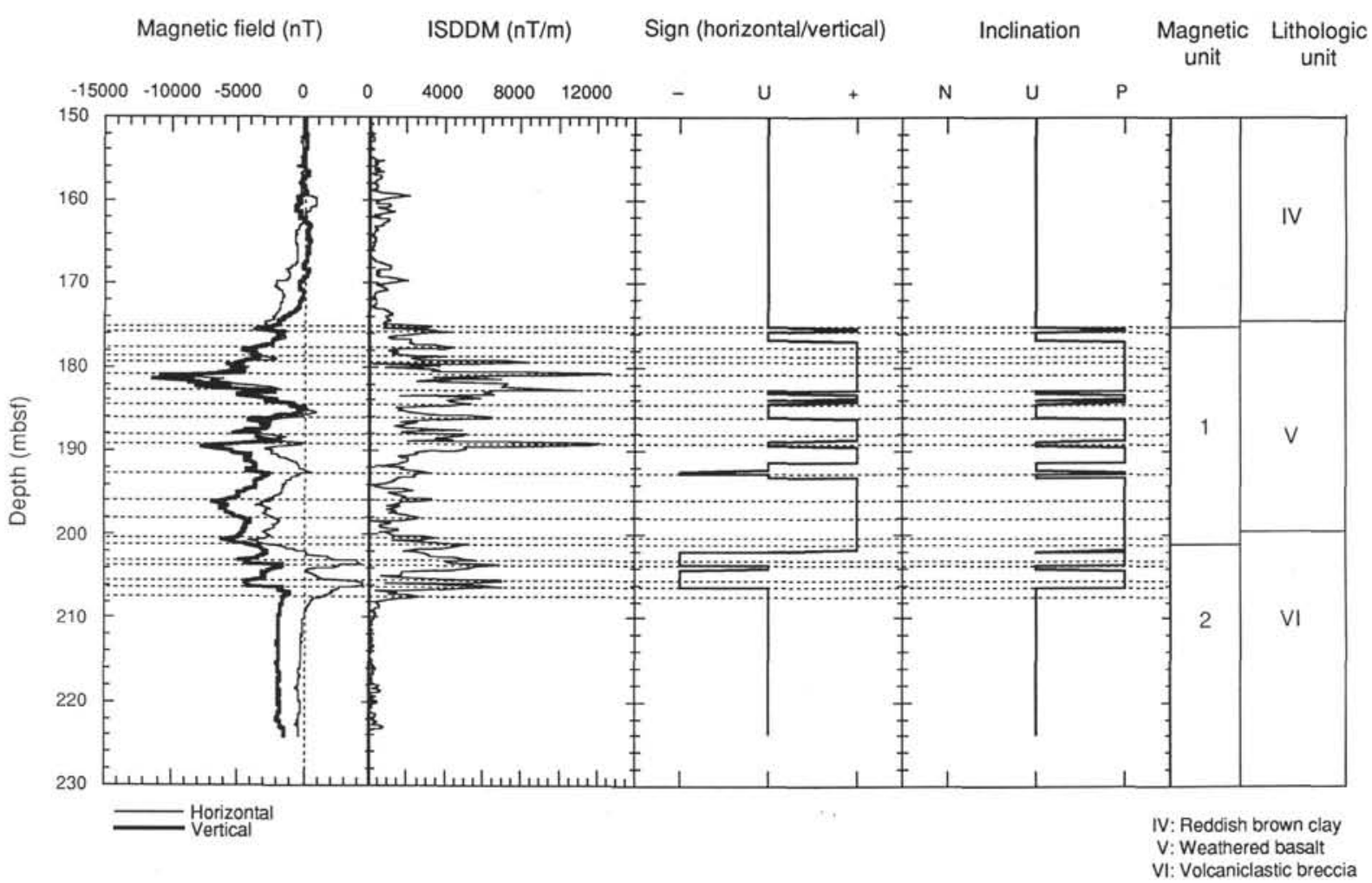

Figure 1. Magnetic properties in Hole 873A (Wodejebato Guyot) from the Schlumberger general purpose inclinometer tool (GPIT). The horizontal dashed lines depict the magnetic boundaries defined from the ISDDM (see Eq. 1 in the text) peaks that are greater than $2000 \mathrm{nT} / \mathrm{m}$. In the "Sign" column, += plus value, $\mathrm{U}=$ uncertainty level, and - = minus value. In the "Inclination" column, $\mathrm{N}=$ negative inclination, $\mathrm{U}=$ uncertainty level, and $\mathrm{P}=$ positive inclination.

Magnetic Unit 1 is characterized by negative $s\left(F_{H}\right)$ and $s\left(F_{Z}\right)$ and by positive $s\left(d F_{Z} / d F_{H}\right)$. These indicate that the magnetization originated in the Southern Hemisphere during a reversed polarity.

In Magnetic Unit 2, positive $s\left(F_{H}\right)$, negative $s\left(F_{Z}\right)$, and negative $s\left(d F_{Z} I d F_{H}\right)$ are observed. These indicate magnetization acquired in the Northern Hemisphere during a normal polarity. Viscous or induced magnetization by the present magnetic field at the site is considered to be the origin of the magnetization within this zone.

Many magnetic boundaries are observed within Magnetic Unit 1 (shown by horizontal dashed lines in Fig. 1). However, both the horizontal and vertical magnetic field components vary with the same sense and those variations do not exceed the present magnetic field level. These suggest that many magnetic boundaries in Magnetic Unit 1 are not caused by changes in magnetic polarity (normal to reversed) but by intensity variations within the same polarity.

The apparent inclination between 175 and $200 \mathrm{mbsf}$ within Magnetic Unit 1 is $21.6^{\circ}$ (Fig. 2). Magnetization originated in the Southern Hemisphere during a reversed magnetic polarity. This value is in good agreement with core-sample paleomagnetic measurements (Nakanishi and Gee, this volume).

\section{Hole 878A (MIT Guyot)}

The FMS/GPIT data from the first set of the measurements within the lower igneous complex (basalt flows with breccia and reddish clay horizons) were analyzed. Two magnetic units were obtained in Hole $878 \mathrm{~A}$ between 815 and $885 \mathrm{mbsf}$ (Fig. 3). In Magnetic Unit 1, the horizontal and vertical components vary with the same sense, and this indicates that magnetization originated in the Southern Hemisphere. Although both the horizontal and vertical components are almost within the uncertainty limits, most of the variations appear to shift toward the positive value relative to the present magnetic field. This suggests that magnetization originated in the Southern Hemisphere during a normal magnetic polarity. However, some variations with opposite sense in horizontal and vertical components (shown by
Table 1. Magnetic polarity and hemisphere of origin determined by the signs of the horizontal and vertical magnetic anomaly components.

\begin{tabular}{llccc}
\hline Hemisphere & Polarity & $s\left(F_{H}\right)$ & $s\left(F_{Z}\right)$ & $s\left(d F_{Z} / d F_{H}\right)$ \\
\hline \multirow{2}{*}{ Northern } & Normal & + & - & - \\
\multirow{3}{*}{ Southern } & Reverse & - & + & - \\
& Normal & + & + & + \\
& Reverse & - & - & +
\end{tabular}

Note: $s\left(F_{H}=\right.$ sign of horizontal field, and $s\left(F_{Z}\right)=$ sign of vertical field.

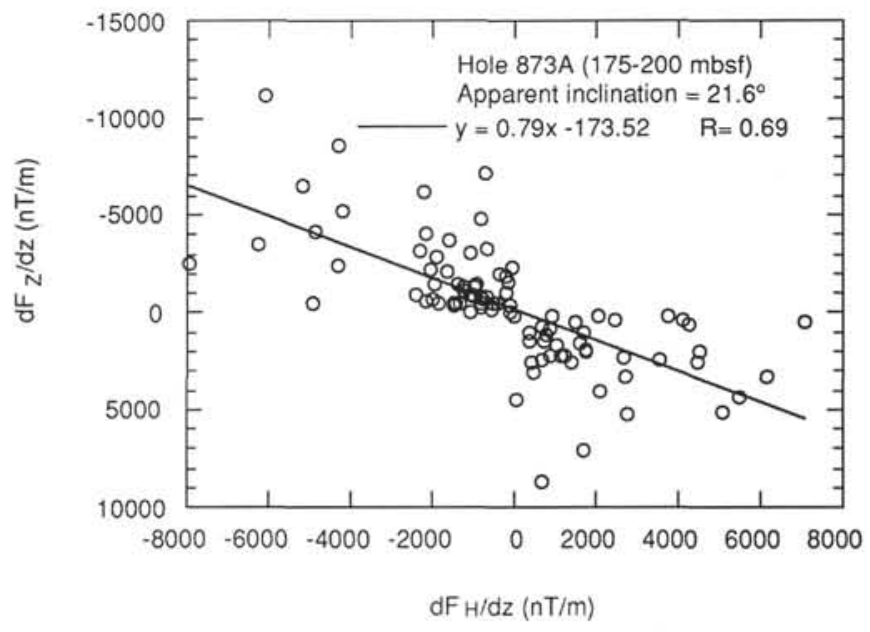

Figure 2. Apparent inclination in Hole 873A (Wodejebato Guyot). 


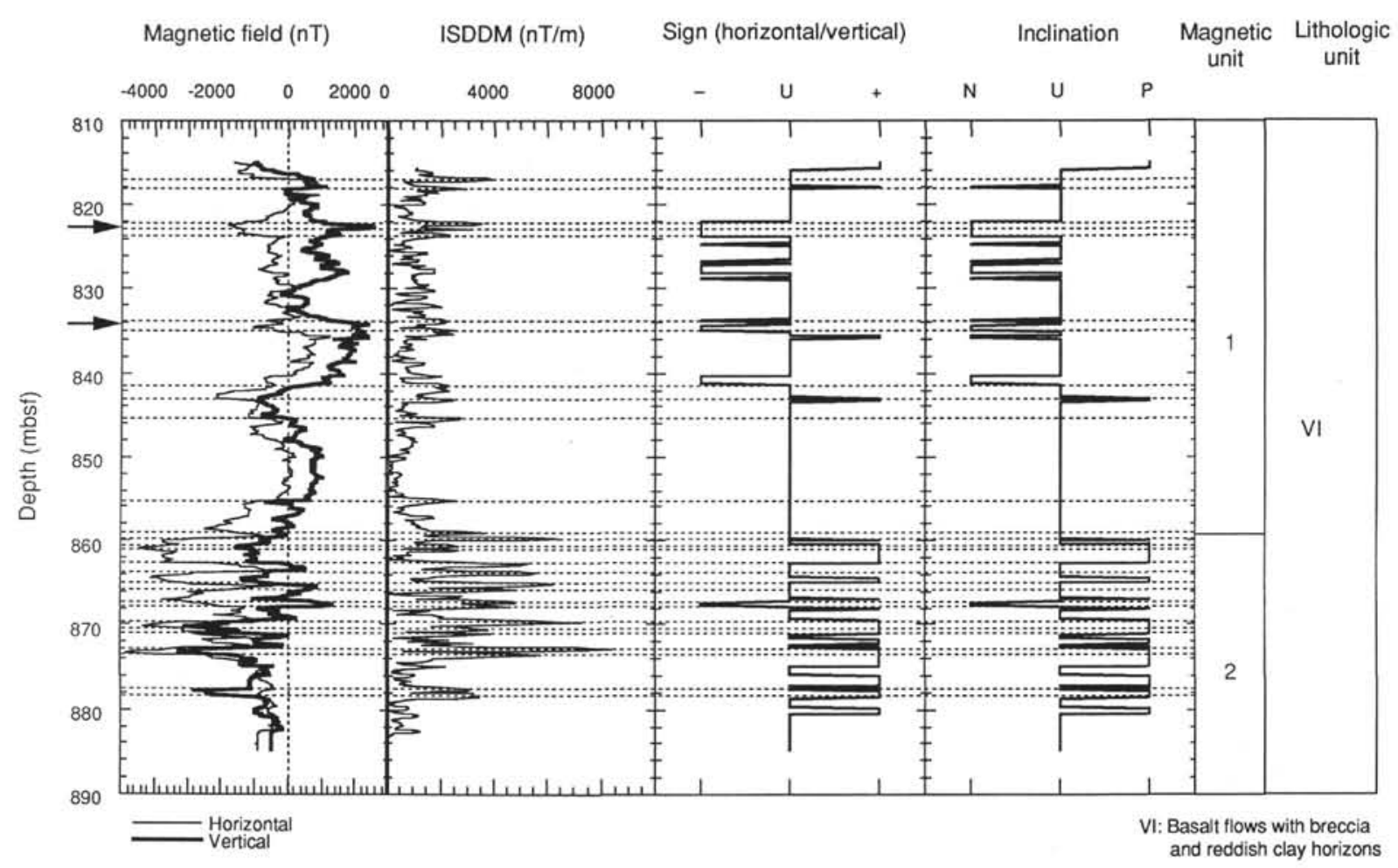

Figure 3. Magnetic properties in Hole 878A (MIT Guyot) obtained with the FMS/GPIT. Arrows show the variations with opposite directions in horizontal and vertical components that show the normal magnetization in the Northern Hemisphere. Notations are the same as in Figure 1.

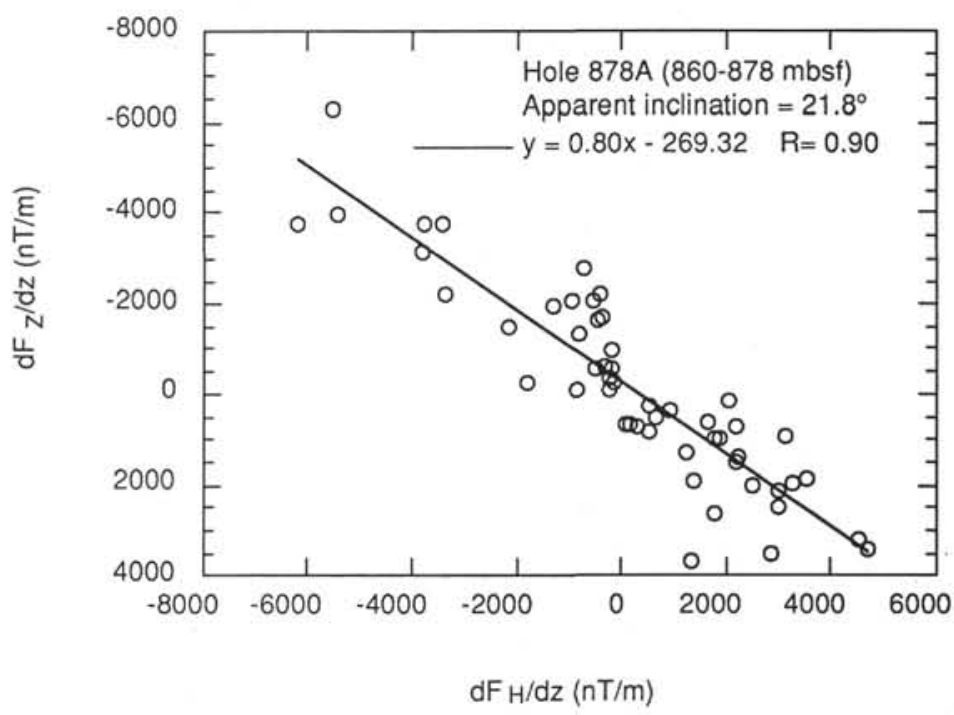

Figure 4. Apparent inclination in Hole 878A (MIT Guyot).

arrows in Fig. 3) show normal magnetization in the Northern Hemisphere. This is possibly caused by viscous or induced magnetization. Viscous or induced magnetization within this unit may disturb the original magnetization.

The upper boundary of Magnetic Unit 2 (at about $860 \mathrm{mbsf}$ ) is denoted by sharp negative $s\left(F_{H}\right)$, negative $s\left(F_{Z}\right)$, and positive $s\left(d F_{Z} / d F_{H}\right)$. Variations within this unit indicate that the magnetization originated in the Southern Hemisphere during a reversed chron.

Many magnetic boundaries were also observed in Hole 878A (shown by horizontal dashed lines in Fig. 3). These boundaries are not caused by changes in magnetic polarity (normal to reversed), but by intensity variations within the same polarity, for the same reason as in Hole 873A.
Apparent inclination within Magnetic Unit 2 is calculated as $21.8^{\circ}$ (Fig. 4). This inclination value coincides with those obtained from the paleomagnetic study of discrete core samples (Nakanishi and Gee, this volume).

\section{Hole 879A (Takuyo-Daisan Guyot)}

There are three magnetic units in Hole 879A (Fig. 5). The boundary between Magnetic Units 2 and 3 at 189 mbsf corresponds to the lithologic unit boundary between upper weathered volcanic breccia and lower peperite basaltic submarine lava flows at about $191 \mathrm{mbsf}$. Magnetic Units 1 and 2 correspond to volcaniclastic breccias. 


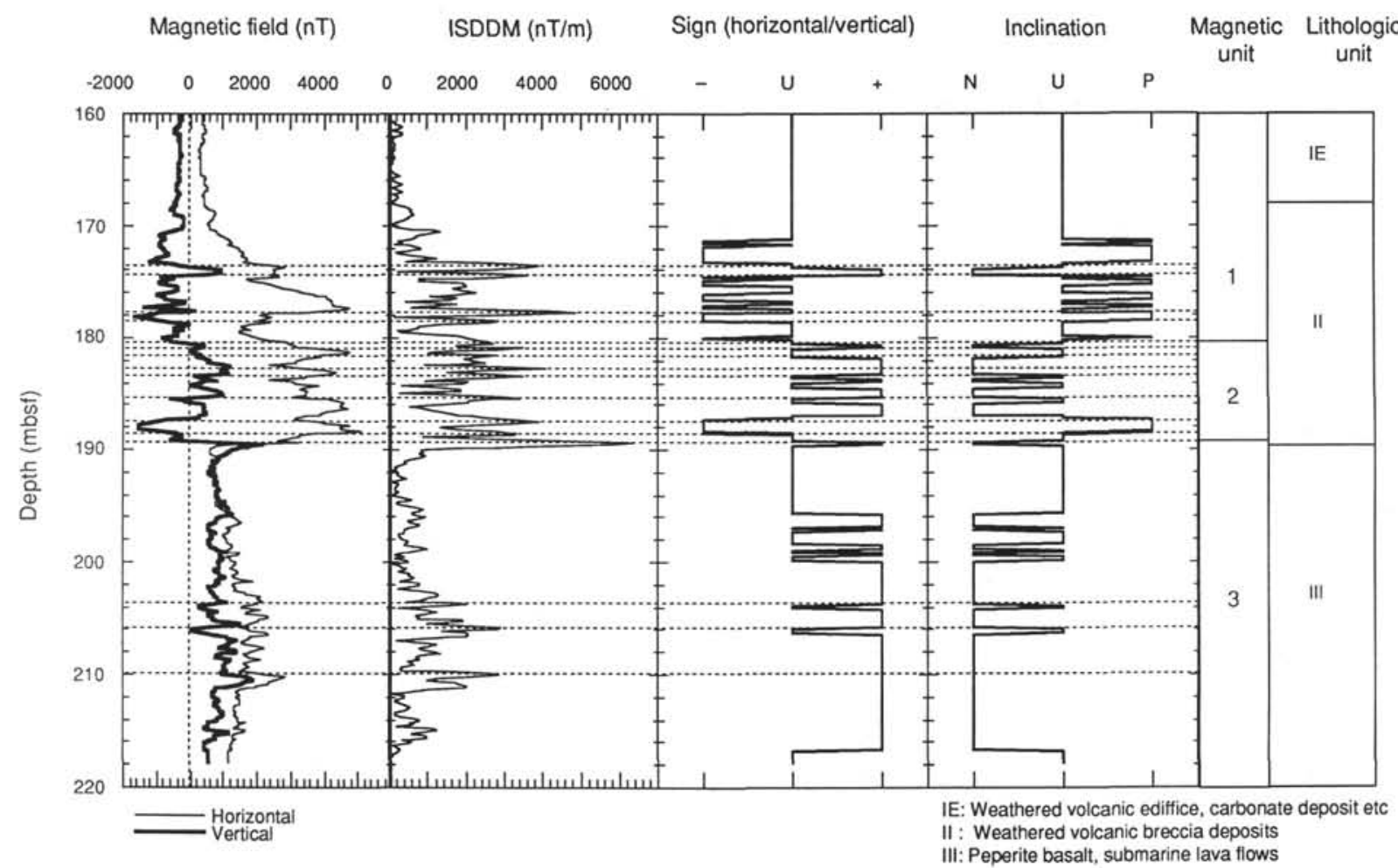

Figure 5. Magnetic properties in Hole 879A (Takuyo-Daisan Guyot) obtained with the FMS/GPIT. Notations are the same as in Figure 1.

Magnetic Unit 1 in the upper part of volcanic breccias is characterized by negative sign (horizontal and vertical variations lie in opposite directions) and positive inclination (Fig. 5). These findings imply that magnetization in Magnetic Unit 1 was acquired in the Northern Hemisphere during a normal chron. On the other hand, Magnetic Unit 2, which corresponds to the lower part of volcanic breccias, is characterized by positive sign (horizontal and vertical variations lie in the same direction) and negative inclination (Fig. 5). These findings suggest that magnetization in Magnetic Unit 2 originated in the Southern Hemisphere during a normal chron. The Northern Hemisphere normal magnetization seen in Magnetic Unit 1 is most likely the origin of viscous or induced magnetization in the present magnetic field.

Positive $s\left(d F_{Z} / d F_{H}\right)$ and the observation that variations in both the horizontal and vertical magnetic components are above the zero level and in the same sense (Fig. 5) imply that the magnetization in Magnetic Unit 3 was acquired in the Southern Hemisphere during a normal chron. Amplitudes of the magnetic variation in Magnetic Unit 3 are smaller that those observed in Magnetic Units 1 and 2. Apparent inclination within this unit is $20.6^{\circ}$ (Fig. 6), concordant with the inclination of characteristic magnetization obtained from the discrete sample paleomagnetic results (Nakanishi and Gee, this volume).

\section{DISCUSSION}

Many magnetic boundaries are present in Holes 873A, 878 A, and $879 \mathrm{~A}$. The magnetic boundaries in the basaltic complex are the result of fine-scale variations with depth in magnetic intensity and are probably associated with individual flows. These amplitude variations may correspond to flow units in the basalt section. For example, many igneous units are reported within lithologic Unit VI (basalt flows with breccia and reddish clay horizons) in Hole 878A, with flow-top breccia at the top of each massive flow unit. We think that the differences in degree of alteration cause short-wavelength magnetic field variations within the same polarity observed by downhole magnetometer logs.

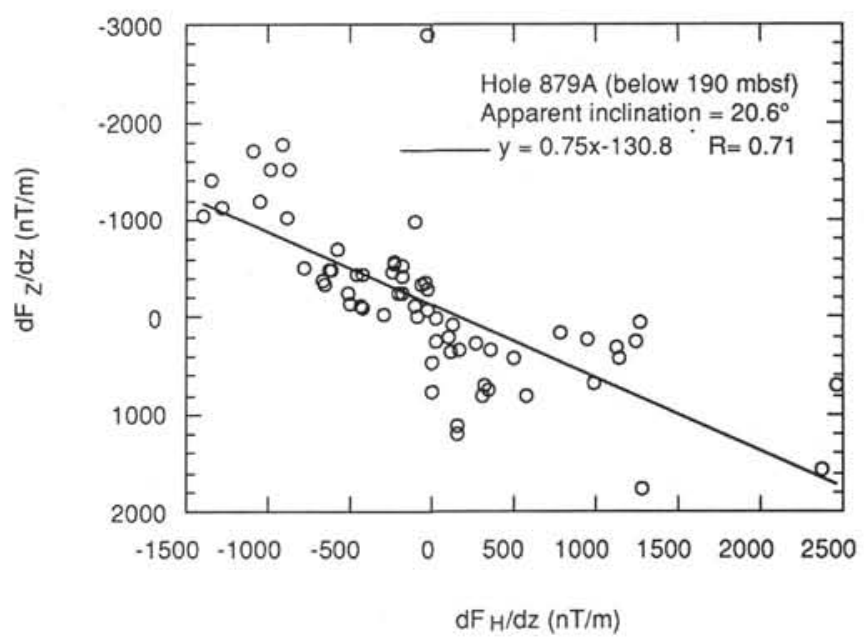

Figure 6. Apparent inclination in Hole 879A (Takuyo-Daisan Guyot).

In Figure 7, downhole magnetometer logging results in Hole 873A (Wodejebato Guyot) are compared with the core-sample paleomagnetic measurements (Nakanishi and Gee, this volume). Core-sample paleomagnetic measurements show that the average inclination for each flow unit in Hole $873 \mathrm{~A}$ is $20.76^{\circ}-23.40^{\circ}$. The average inclination of Site 873 is $22.97^{\circ}$. These measurements are in good agreement with the apparent inclination results $\left(21.6^{\circ}\right)$ calculated from FMS/GPIT data between 175 and $200 \mathrm{mbsf}$ (weathered basalt section), where both $s\left(d F_{Z} / d F_{H}\right)$ and inclination are positive. Although a few estimates of Q are available from core samples in Hole 873A, those from other holes in Wodejebato Guyot generally have high a Q ratio (Fig. 7). This high Q ratio might be the main reason for the good agreement among inclination values from cores and downhole measurements. 


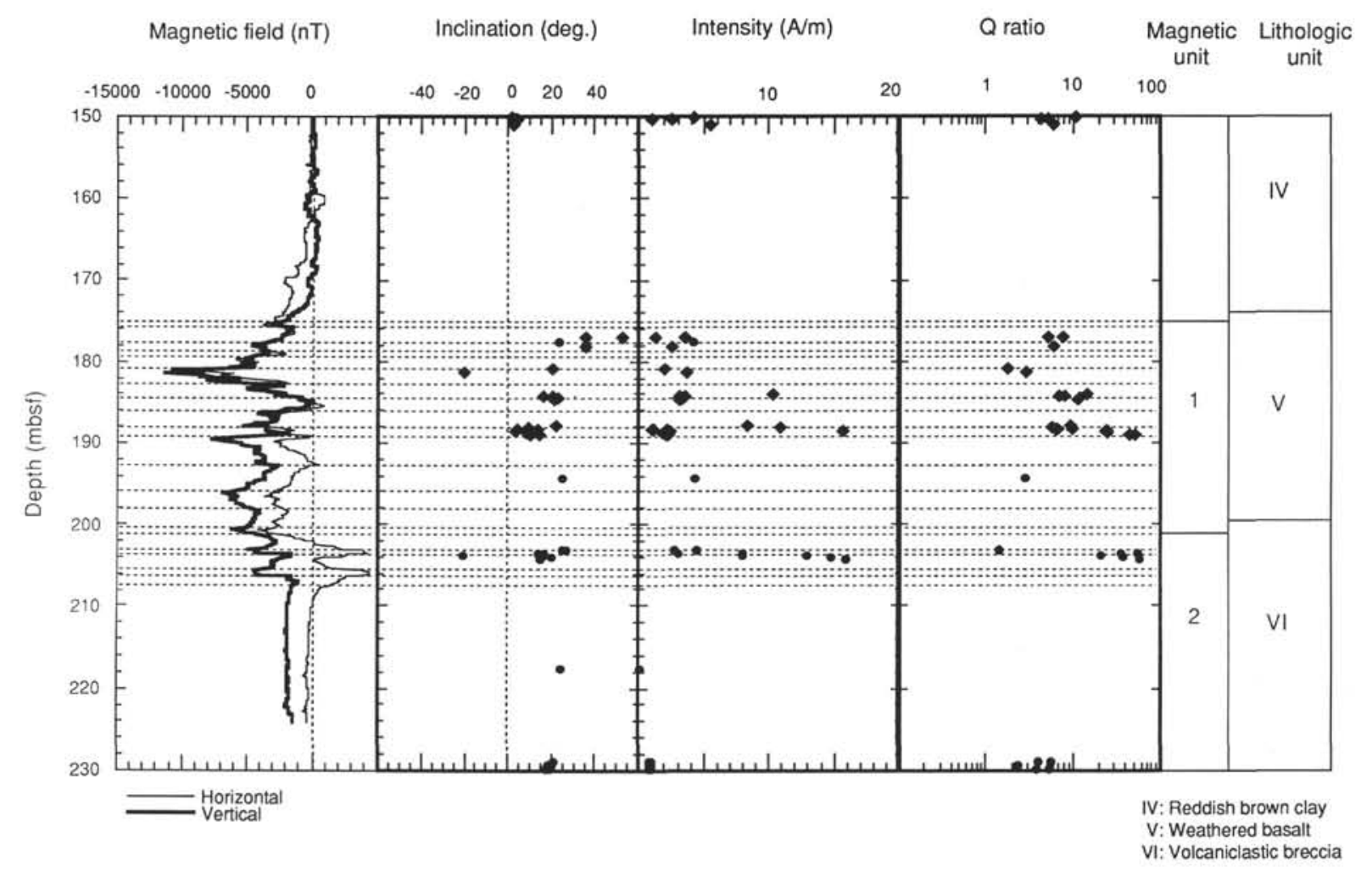

Figure 7. Comparison of the downhole magnetic field data in Hole 873A (Wodejebato Guyot), obtained with the Schlumberger FMS/GPIT tool, vs. the results of core-sample measurements in Wodejebato Guyot obtained by Nakanishi and Gee (this volume). The downhole magnetometer data is only from Hole $873 \mathrm{~A}$, whereas the core measurements are for Hole 873A (solid circles) as well as Holes 874B, 875C, 876A, and 877A (solid diamonds).

According to the paleomagnetic measurements from Hole $878 \mathrm{~A}$ in MIT Guyot (Nakanishi and Gee, this volume), the magnetic polarity shallower than Core 144-878A-86R (about $802 \mathrm{mbsf}$ ) is normal and that below Section 144-878A-90R-4 (about 839 mbsf) is reversed. The average inclination of the samples with reversed polarity is $21.31^{\circ}$. The apparent inclination from downhole data calculated below $860 \mathrm{mbsf}$ in basalt flows of the reversed polarity section is $21.8^{\circ}$. The apparent inclination $\left(21.8^{\circ}\right)$ is in excellent agreement with the paleomagnetic data $\left(21.31^{\circ}\right)$. Although some samples have an extremely low Q ratio (Nakanishi and Gee, this volume), these samples also possess a low intensity value (Fig. 8). This may be the reason for the excellent agreement in inclination from core sample measurements and downhole data, because the data with low intensity do not contribute to the inclination calculation.

The average inclination from core-sample measurements of Takuyo-Daisan Guyot is $-18.39^{\circ}$ (Nakanishi and Gee, this volume). The apparent inclination calculated from the downhole magnetometer is $-20.6^{\circ}$, which agrees well with the paleomagnetic result within the $95 \%$ confidence limits of Nakanishi and Gee (this volume). Because the Q ratio of the core sample is extremely high (Fig. 9), induced magnetization is negligible in Hole 879A.

The apparent inclination was calculated only for the basalt section in Holes 873A, 878A, and 879A. Magnetization in Holes 873A and $878 \mathrm{~A}$ shows a Southern Hemisphere origin during a reversed chron. Southern Hemisphere reversed magnetization possibly shows the primary magnetization, because these sites are located in the Northern Hemisphere and the apparent inclination value is in good agreement with that from the paleomagnetic results. It is also shown that Southern Hemisphere normal magnetization is possibly the primary magnetization in Hole 879A.

However, if we take into account the effect of induced magnetization, observed inclination becomes steeper for the Southern Hemisphere reversed magnetization. On the other hand, observed incli- nation becomes shallower for Southern Hemisphere normal magnetization. Therefore, the apparent inclination obtained in Hole 873A and $878 \mathrm{~A}$ indicates an upper limit of the inclination value, and that obtained in Hole 879A indicates a lower limit of inclination value.

Significant contribution from induced magnetization was not observed in the downhole magnetometer results in the basalt section of Holes 873A, 878A, and 879A. Gee et al. (1989) suggested that induced magnetization significantly contributes to seamount magnetization. Results from the downhole magnetometer logs obtained during Leg 143 in the Mid-Pacific Mountains also implies significant contribution of induced magnetization to the seamount magnetization (Nogi et al., 1993b). Gee and Nakanishi (1994) calculated a mean Q ratio of 9.8 and pointed out the importance of induced magnetization contribution of approximately $10 \%$ for Leg 144 data.

Nakanishi and Gee (this volume) found differences in the paleolatitude results between those from seamount magnetic anomaly modeling and paleomagnetic measurements on core samples for LoEn, MIT, and Takuyo-Daisan guyots. They interpreted that the discrepancy in paleolatitude is the result of a significant contribution from viscous and induced magnetization. However, apparent inclination values determined in the upper basaltic section from the downhole magnetometer logs in this study are almost the same as those obtained from the core-sample paleomagnetic study. Although the present downhole magnetometer results from the breccia sections show induced or viscous effects, results from the basalt section clearly show that these contributions are negligible in Holes 873A, $878 \mathrm{~A}$, and $879 \mathrm{~A}$ as far as the upper basalt section are concerned.

Sager and Pringle (1988) also suggest that seamount magnetizations derived from seamount magnetic anomalies are almost the same as those obtained from dredged samples and that the induced magnetization of seamounts is negligible: It is possible that there are two types of seamounts: those with a low $\mathrm{Q}$ ratio and those with a high $\mathrm{Q}$ ratio. These types may be related to the source of the basalt and 


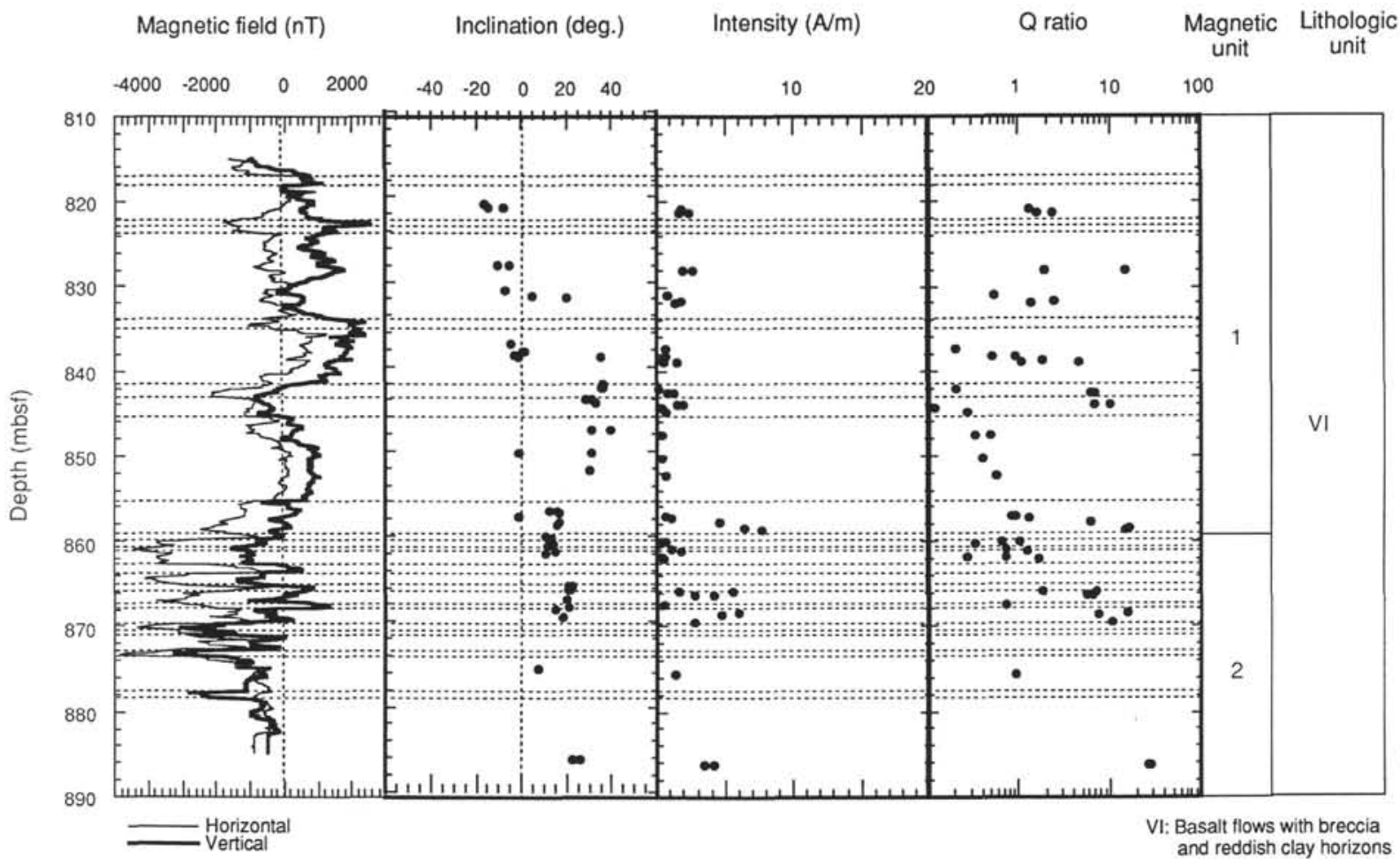

Figure 8. Comparison of downhole magnetic field data in Hole 878A (MIT Guyot), obtained with the Schlumberger FMS/GPIT, vs. the results of core-sample measurements obtained by Nakanishi and Gee (this volume).

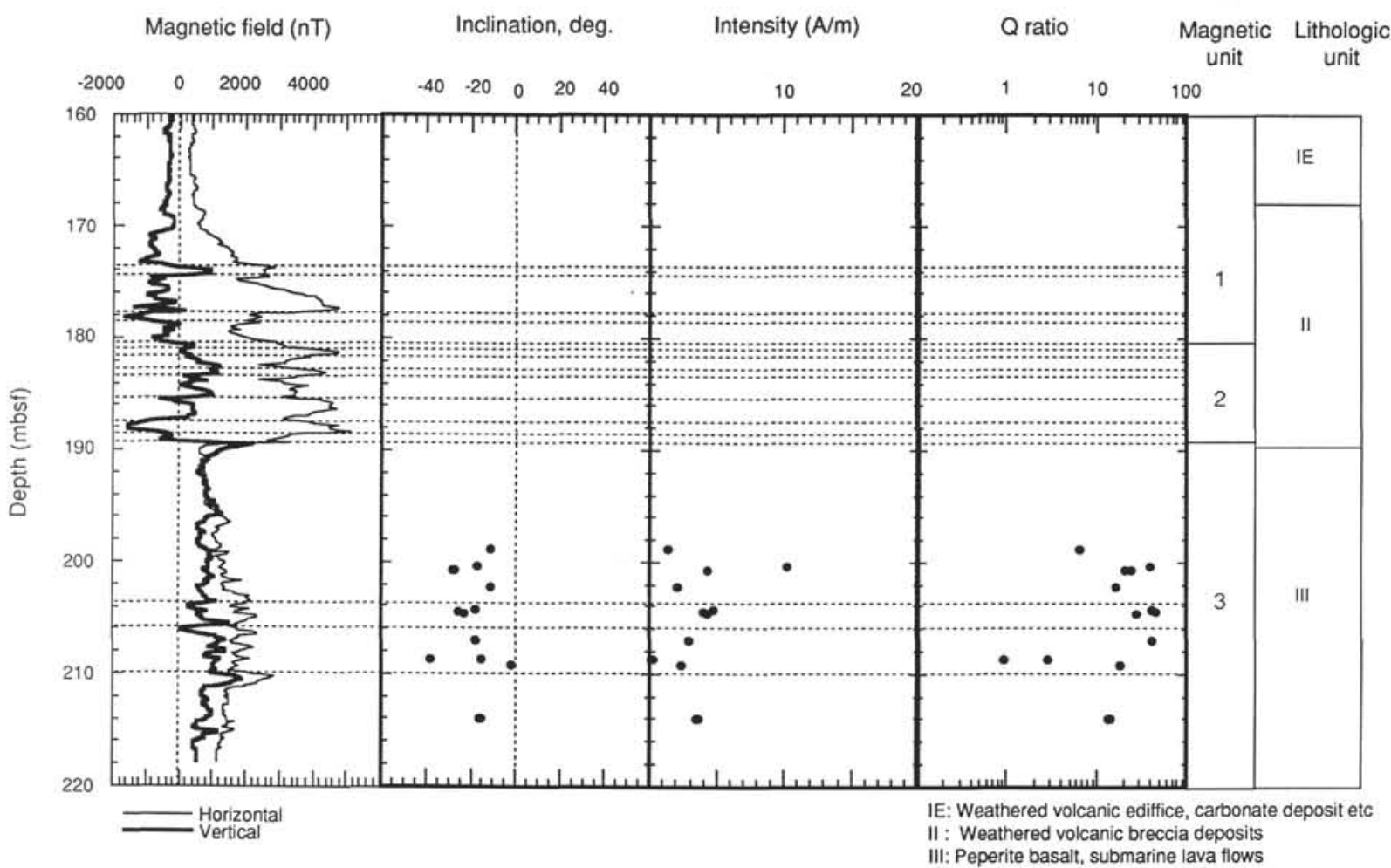

Figure 9. Comparison of downhole magnetic field data in Hole 879A (Takuyo-Daisan Guyot), obtained with the Schlumberger FMS/GPIT, vs. the results of core-sample measurements obtained by Nakanishi and Gee (this volume). 
environment on and after forming basalt. Further investigation is required for elucidating the nature of seamount magnetization.

If there is a contribution from induced and/or viscous magnetization, it might be from breccia and/or basalts in sections deeper than the present study. The magnetic field in the deeper section of basalts may contribute the magnetic character in these sites.

The insufficient data quality of GPIT (insufficient resolution and drifts) prohibited an analysis of the data below the "uncertainty limit." Nogi et al. (in press a and b) and Ito et al. (this volume) demonstrated the usefulness of a three-component downhole magnetometer. It is necessary to develop a more reliable downhole magnetometer system (with sufficient data resolution, orientation tool, and susceptibility tool) to use its potential advantages fully.

\section{CONCLUSIONS}

We determined uniquely the polarity (normal or reverse) and hemisphere of origin (North or South) of remanent magnetization by inspection of the signs (positive or negative) and variations of the horizontal and vertical magnetic anomaly components from a threecomponent downhole magnetometer. Southern Hemisphere reversed magnetization in the basalt sections in Hole $873 \mathrm{~A}$ and $878 \mathrm{~A}$ possibly shows the primary magnetization. We also showed that Southern Hemisphere normal magnetization probably displays the primary magnetization in Hole 879A.

Apparent inclination values from the downhole magnetometer log used in this study are almost the same as those obtained from the core-sample paleomagnetic study. This indicates a high $\mathrm{Q}$ ratio and suggests that induced magnetization is negligible. We suggest that there are two types of seamounts: those with a low $Q$ ratio and those with a high $\mathrm{Q}$ ratio.

\section{ACKNOWLEDGMENTS}

We thank all the shipboard party for their kind help and encouragement. We are grateful to the members of the Geothermal Research Department, Geological Survey of Japan, and the Geochemical Research Department, Meteorological Research Institute, for their encouragement and understanding. We thank the Ocean Research Institute, the University of Tokyo, and ODP for providing us the opportunity to participate on Leg 144. We also are grateful to Toshitugu Yamazaki for discussion. Critical reviews by Nobuaki Niitsuma and Marcia McNutt are also appreciated. Masao Nakanishi and Jeffrey Gee kindly showed us their paleomagnetic results.

\section{REFERENCES $*$}

Bosum, W., and Kopietz, J., 1990. BGR magnetometer logging in Hole 395A, Leg 109. In Detrick, R., Honnorez, J., Bryan, W.B., Juteau, T., et al., Proc. ODP, Sci. Results, 106/109: College Station, TX (Ocean Drilling Program), 309-313.

Bosum, W., and Scott, J.H., 1988. Interpretation of magnetic logs in basalt, Hole 418A. In Salisbury, M.H., Scott, J.H., et al., Proc. ODP, Sci. Results, 102: College Station, TX (Ocean Drilling Program), 77-95.

Furuta, T., Tonouchi, S., and Nakada, M., 1980. Magnetic properties of pillow basalt from the Kinan seamount chain, the Shikoku Basin. J. Geomagn. Geoelectr., 32:567-573.

Gallet, Y., and Courtillot, V., 1989. Modeling magnetostratigraphy in a borehole. Geophysics, 54:973-983.

Gee, J., and Nakanishi, M., 1994. Magnetic petrology and magnetic properties of western Pacific guyots (ODP Leg 144). Eos, 75:127.
Gee, J., Staudigel, H., and Tauxe, L., 1989. Contribution of induced magnetization to magnetization of seamounts. Nature, 342:170-173.

Gee, J., Tauxe, L., Hildebrand, J.A., Staudigel, H., and Lonsdale, P., 1988. Non-uniform magnetization of Jasper Seamount. J. Geophys. Res., 93:12159-12175.

Hamano, Y., and Kinoshita, H., 1990. Magnetization of the oceanic crust inferred from magnetic logging in Hole 395A. In Detrick, R., Honnorez, J., Bryan, W.B., Juteau, T., et al., Proc. ODP, Sci. Results, 106/109: College Station, TX (Ocean Drilling Program), 223-229.

Kikawa, E., and Pariso, J.E., 1991. Magnetic properties of gabbros from Hole 735B, Southwest Indian Ridge. In Von Herzen, R.P., Robinson, P.T., et al., Proc. ODP, Sci. Results, 118: College Station, TX (Ocean Drilling Program), 285-307.

Kinoshita, H., Furuta, T., and Pariso, J., 1989. Downhole magnetic field measurements and paleomagnetism, Hole 504B, Costa Rica Ridge. In Becker, K., Sakai, H., et al., Proc. ODP, Sci. Results, 111: College Station, TX (Ocean Drilling Program), 147-156.

Kono, M., 1980. Paleomagnetism of DSDP Leg 55 basalts and implications for the tectonics of the Pacific plate. In Jackson, E.D., Koizumi, I., et al., Init. Repts. DSDP, 55: Washington (U.S. Govt. Printing Office), 737-752.

Nogi, Y., Taruduno, J.A., and Sager, W.W., in press a. Geomagnetic field variations recorded in ODP drill pipes and their implications for paleomagnetic studies. In Winterer, E.L., Sager, W.W., Firth, J.V., and Sinton, J.M. (Eds.), Proc. ODP, Sci. Results, 143: College Station, TX (Ocean Drilling Program).

, in press $\mathrm{b}$. Inferences on the nature and origin of basalt sequences from the Cretaceous Mid-Pacific Mountains ODP Sites 865 and 866 as deduced from downhole magnetometer logs. In Winterer, E.L., Sager, W.W., Firth, J.V., and Sinton, J.M. (Eds.), Proc. ODP, Sci. Results, 143: College Station, TX (Ocean Drilling Program).

, in press c. Magnetization of seamounts derived sediments (ODP Site 869) inferred from Leg 143 downhole magnetometer logs. In Winterer, E.L., Sager, W.W., Firth, J.V., and Sinton, J.M. (Eds.), Proc. ODP, Sci. Results, 143: College Station, TX (Ocean Drilling Program).

Pariso, J.E., and Johnson, H.P., 1993. Do layer 3 rocks make a significant contribution to marine magnetic anomalies? In situ magnetization of gabbros at Ocean Drilling Program Hole 735B. J. Geophys. Res., 98:16033-16052.

Pozzi, J.-P., Martin, J.P., Pocachard, J., Feinberg, H., and Galdeano, A., 1988. In situ magnetostratigraphy: interpretation of magnetic logging in sediments. Earth Planet. Sci. Lett., 88:357-373.

Sager, W.W., Duncan, R.A., and Handschumacher, D.W., 1993. Paleomagnetism of the Japanese and Marcus-Wake seamounts, Western Pacific Ocean. In Pringle, M.S., Sager, W.W., Sliter, W.V., and Stein, S. (Eds.), The Mesozoic Pacific: Geology, Tectonics, and Volcanism. Geophys. Monogr., Am. Geophys. Union, 77:401-435.

Sager, W.W., and Han, H.-C., 1993. Rapid formation of the Shatsky Rise oceanic plateau inferred from its magnetic anomaly. Nature, 364:610-613.

Sager, W.W., and Pringle, M.S., 1988. Mid-Cretaceous to Early Tertiary apparent polar wander path of the Pacific Plate. J. Geophys. Res., 93:11753-11771.

Savitzky, A., and Golay, M.J.E., 1964. Smoothing and differential of data by simplified least square procedure. Anal. Chem., 36:1627-1639.

Shipboard Scientific Party, 1993. Site 878. In Premoli Silva, I., Haggerty, J., Rack, F., et al., Proc. ODP, Init. Repts., 144: College Station, TX (Ocean Drilling Program), 331-412.

\footnotetext{
Abbreviations for names of organizations and publications in ODP reference lists follow the style given in Chemical Abstracts Service Source Index (published by American Chemical Society).
}

Date of initial receipt: 3 February 1994

Date of acceptance: 13 July 1994

Ms 144SR-021 